\title{
Simulasi Performa Turbin Propeller Dengan Sudut Pitch Yang Divariasikan
}

\author{
Pribadyo $^{1,4, *}$, Hadiyanto, $\mathbf{H}^{\mathbf{1}, \mathbf{2}}$, and Jamari, $\mathbf{J}^{\mathbf{3}}$ \\ ${ }^{I}$ Program Doktor Ilmu Lingkungan, Sekolah Pascasarjana, Universitas Diponegoro, Semarang \\ ${ }^{2}$ Departemen Teknik Kimia, Fakultas Teknik, Universitas Diponegoro, Semarang, Indonesia. \\ ${ }^{3}$ Departemen Teknik Mesin, Fakultas Teknik, Universitas Diponegoro, Semarang, Indonesia. \\ ${ }^{4}$ Jurusan Teknik Mesin Fakultas Teknik Universitas Teuku Umar, Meulaboh, Indonesia \\ e-mail:*dyo_1806@yahoo.co.id, ${ }^{2}$ hady.hadiyanto@gmail.com, ${ }^{3}$ j.jamari@gmail.com
}

\begin{abstract}
Abstrak
Performansi turbin Propeller dapat ditingkatkan dengan cara mengubah parameter desain turbin. Salah satu metode yang dikembangkan yaitu dengan memvariaikan sudut sudu pada bilah turbin. Analisis pengaruh sudut sudu terhadap performansi turbin propeller dilakukan melalui simulasi numerik berbasis dinamika fluida komputasi. Simulasi dilakukan dengan variasi sudut sudu turbin propeller $18^{\circ}, 23^{\circ}$, dan $28^{\circ}$ pada kecepatan aliran $0,08 \mathrm{~m} / \mathrm{s}$ sampai dengan $0,5 \mathrm{~m} / \mathrm{s}$. Hasil simulasi menunjukkan turbin dengan sudut sudu $18^{0}$ memiliki performansi terbaik dibandingkan dengan sudut sudu turbin $23^{\circ}$ dan $28^{\circ}$. Sedangkan untuk sudut sudu turbin $23^{0}$ cenderung memiliki performa yang lebih tinggi dibandingkan dengan sudut $28^{0}$ meskipun keduanya memiliki puncak nilai koefisen daya $\left(C_{P}\right)$ yang berkesesuaian.
\end{abstract}

Kata kunci-Turbin propeller, bilah pelari, sudut sudu, simulasi CFD

\begin{abstract}
Propeller turbine performance can be improved by changing the turbine design parameters. One method that was developed is to vary the blade angle on the runner's blades. Analysis of the influence of blade angle on propeller turbine performance is done through numerical simulations based on computational fluid dynamics. The simulation is done with variations of propeller turbine blade angles of $18^{\circ}, 23^{\circ}$, and $28^{\circ}$ at flow rates of $0.08 \mathrm{~m} / \mathrm{s}$ to 0.5 $\mathrm{m} / \mathrm{s}$. Simulation results show turbines with 250 blade angles have the best performance compared to turbine blade angles of $23^{\circ}$ and $28^{0}$. While the turbine blade angles of $23^{\circ}$ tend to have higher performance compared to angles of $28^{0}$ even though both have peak values for the corresponding power coefficient.
\end{abstract}

Keywords-Propeller turbine, runner blade, pitch angle, CFD simulation

\section{PENDAHULUAN}

$\mathrm{P}$ emanfaatan tenaga air sebagai pembangkit listrik adalah salah satu bentuk teknologi hijau yang murah dan ramah lingkungan, dan sangat penting untuk masa depan yang berkelanjutan [1]. Pembangkit listrik tenaga air telah terbukti menghasilkan sekitar 16 persen kebutuhan energi listrik dunia dan memainkan peranan yang sangat penting dilebih dari seratus limapuluh negara. Kanada, Cina dan Amerika Serikat adalah negara-negara yang memiliki kapasitas pembangkit listrik tenaga air terbesar [2, 3]. 
Selain lebih efisien tenaga air adalah sumber energi terbarukan terbaik dari pada energi angin atau matahari serta memiliki nilai kompetitif bila dibandingkan dengan pembangkit fosil $[4,5]$.

Sebagai negara kepulauan, Indonesia memiliki banyak potensi tenaga air yang tersebar dari Sabang sampai Merauke, namun demikian baru sekitar 9,4 persen yang termanfaatkan [6]. Beberapa kendala yang menyebabkan rendahnya pemanfaatan potensi energi hijau yang tersedia diantaranya adalah investasi yang besar, kendala geografi dimana potensi tersebut berada serta minimnya sumber daya manusia yang dapat mengoperasikan dan merawat sistem pembangkit yang ada [7]. Salah satu potensi aliran air yang belum banyak terpakai saat ini adalah potensi dengan head yang tergolong rendah. Potensi ini sangat besar dan banyak, hanya saja belum tereksploitasi dengan baik karena keterbatasan turbin konvensional yang ada saat ini. Turbin yang banyak dimanfaatkan untuk potensi head yang rendah diantarannya adalah turbin Propeller yang dapat beroperasi pada kisaran head 2 hingga 40 meter [8], dan digolongkan dalam pembangkit listrik skala kecil.

Aspek utama dari setiap pembangkit listrik skala kecil adalah turbin yang mampu menghasilkan listrik dengan daya maksimum melalui putaran poros. Sesuai dengan karakteristik dari turbin air, dimana hubungan daya dengan putaran turbin adalah daya akan turun setelah putaran propeller mencapai putaran tertentu. Pada putaran yang relatif rendah, semakin besar putaran propeller maka daya akan meningkat dan pada saat putaran propeller mencapai kondisi stall maka daya akan drop secara perlahan-lahan [9]. Karenanya banyak perhatian khusus yang harus dipahami dalam perancangan turbin salah satunya adalah desain sudu untuk kinerja turbin yang optimal $[10,11,12,13]$. Mengingat Sudu turbin adalah komponen utama dalam turbin propeller yang langsung terhubung ke poros dan dihubungkan bersama dengan generator. Dengan demikian kecepatan putar generator yang menghasilkan output daya, serta kecepatan poros tergantung pada putaran bilah pelari.

Berdasarkan jenis dan konstruksinya, turbin propeller yang dikembangkan saat ini adalah dengan desain sudut yang divariasikan. Meskipun hasil studi numerik dan eksperimen telah menunjukkan bahwa turbin ini dapat bekerja dengan performa yang baik dalam aplikasinya $[14,15,16,17,18]$, namun penulis berharap dapat meningkatkan aplikasi dan keunggulan turbin jenis ini dalam memanfaatkan potensi energi yang ada. Untuk alasan tersebut, maka studi dan desain turbin ini dikembangkan dengan sudut pitch divariasi $18^{\circ}, 23^{\circ}$, dan $28^{0}$ yang belum banyak diteliti oleh para peneliti sebelumnya untuk kasus turbin ini. Untuk keperluan studi maka sudu turbin di desain untuk kondisi operasi dengan debit antara $0,08 \mathrm{~m} / \mathrm{s}$ sampai dengan $0,5 \mathrm{~m} / \mathrm{s}$ pada putaran $750 \mathrm{rpm}$. Diameter hub dan tip yang direncanakan adalah 0,30 meter dan 0,06 meter dengan Jumlah sudu 4 buah dengan ketebalan plat $3 \mathrm{~mm}$.

\section{METODE PENELITIAN}

Penentuan geometri yang digunakan dalam simulasi ini adalah representasi dari fluida negatif yang mengalir pada sekitar propeller. Model CAD dibuat menggunakan software Autodesk Inventor yang diekpor dalam format IGES sehingga kompatibel dengan environment ANSYS terutama untuk meshing. Seperti telah disebutkan sebelumnya model terdiri dari tiga variasi sudut pitch $18^{\circ}, 23^{\circ}$, dan $28^{\circ}$, dengan parameter-parameter geometri lainya seperti diameter hub adalah 0,30 m, diameter tip 0,06 $\mathrm{m}$, untuk keperluan simulasi jumlah sudu adalah 4 buah. Gambar 1 memperlihatkan visualisasi bilah pelari untuk masing-masing sudut.

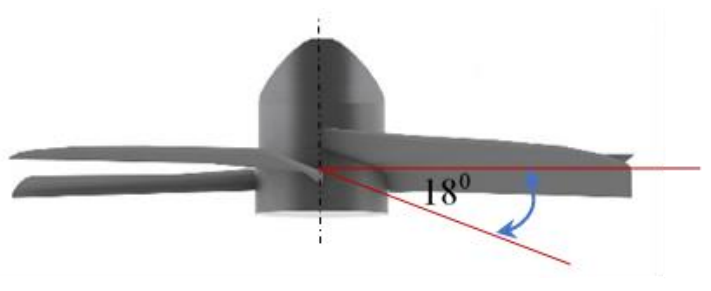

(a) Bilah pelari dengan sudut $18^{0}$

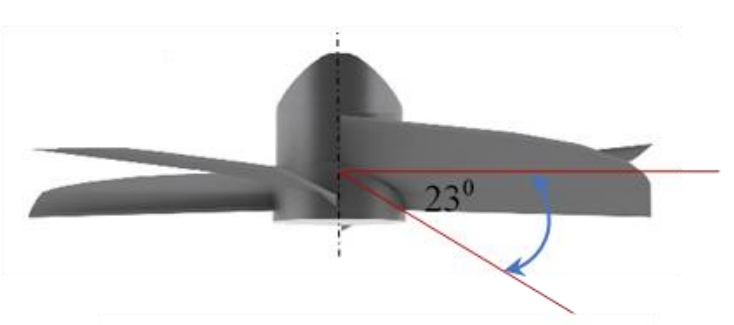

(b) Bilah pelari dengan sudut $23^{0}$ 


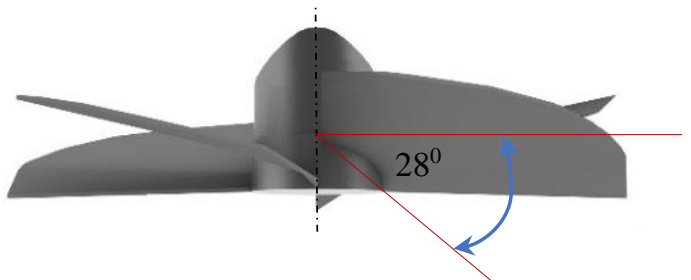

(c) Bilah pelari dengan sudut $28^{0}$

Gambar 1 Tampilan bilah pelari dengan sudut a). $18^{0}$, b). $23^{0}$, dan c). $28^{0}$

Sebelum diproses lebih lanjut di ANSYS FLUENT, geometri harus diberikan identitasnya masing-masing pada permukaannya sehingga dapat didefinisikan parameterparameter untuk kepentingan analisis, seperti input data inlet, outlet, serta dinding-dinding bilah untuk pengambilan data yang ditunjukkan dalam gambar 2 .

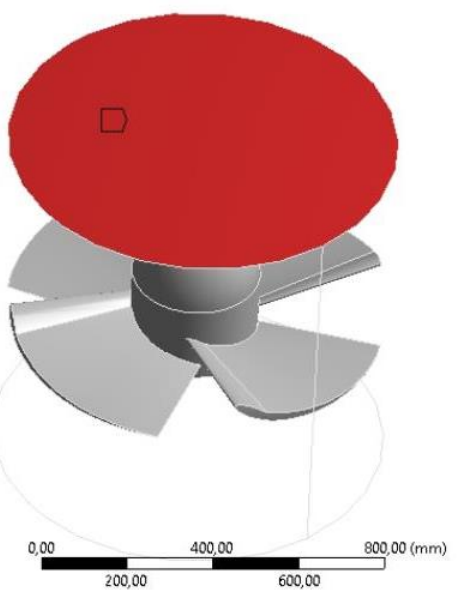

(a) Lokasi inlet

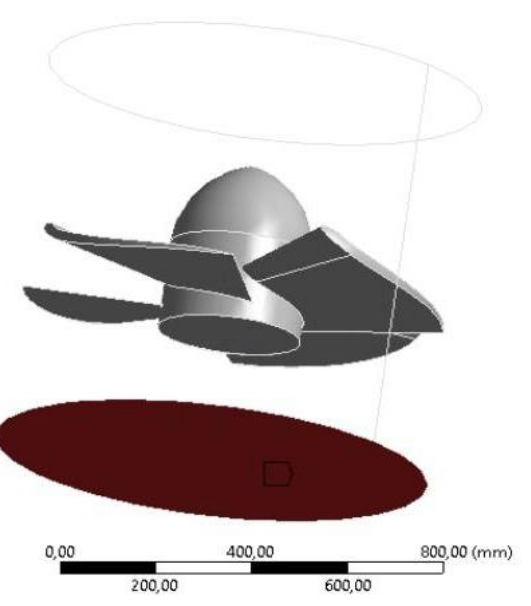

(b) Lokasi outlet

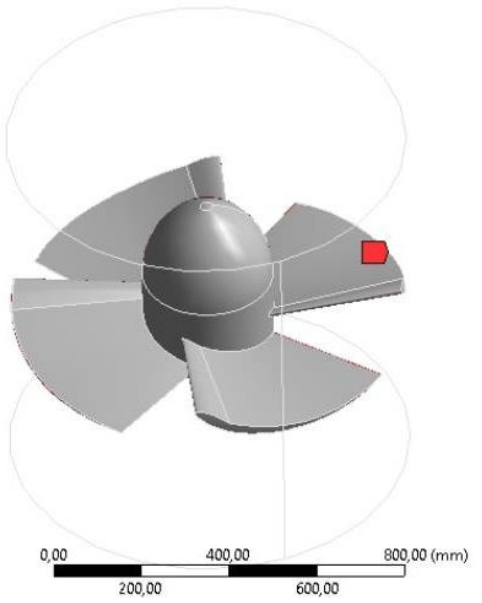

(c) Permukaan bilah

Gambar 2 Lokasi pemberian identitas pada a). lokasi inlet, b). lokasi outlet dan c). permukaan bilah

Proses konversi domain fluida yang kontinyu menjadi domain komputasi yang diskrit, sehingga parameter-parameter fluida yang ada dalam domain tersebut dapat diselesaikan menggunakan metode numerik, dalam kasus ini computational fluid dynamics (CFD) menggunakan bantuan software ANSYS FLUENT. Sementara face sizing (gambar 3 a) digunakan untuk menghasilkan mesh yang padat pada daerah sekitar permukaan yang dipilih, yaitu bilah. Hal ini dilakukan agar mesh yang dihasilkan memberikan hasil yang akurat namun tidak memakan banyak memori komputasi untuk daerah yang tidak menjadi fokus analisis. Sedangkan seting body sizing (gambar 3 b) digunakan untuk memastikan ukuran mesh yang seragam pada seluruh domain komputasi. Dalam seting komputasi yang dimaksudkan dalam analisis ini adalah input-input metode komputasi serta data-data berupa boundary conditions untuk masing-masing setingan yang digunakan dan dijelaskan sebagai berikut:

1. Seting waktu yang digunakan dalam simulasi ini adalah steady, atau aliran tidak dipengaruhi oleh faktor waktu. Metode rotasi yang digunakan dalam simulasi ini adalah metode moving wall pada dinding rotor sehingga tidak diperlukan simulasi transient. 
2. Model turbulen k-omega adalah model turbulen yang paling banyak digunakan untuk siumulasi aliran dengan adverse pressure gradient (aliran yang tidak natural) seperti turbin, pompa, kompresor dll namun memiliki kelemahan pada aliran free stream (aliran jauh dari dinding), sehingga persamaan turbulen tersebut dimodifikasi dengan metode SST.

3. Material yang digunakan dalam simulasi ini adalah air dengan fasa cair yang merepresentasikan kondisi operasional turbin air tersebut.

4. Imulasi ini bertujuan untuk menentukan performa turbin pada berbagai kondisi operasional dengan acuan parameter tip speed ratio (TSR), sehingga kecepatan inlet divariasikan sedemikian rupa hingga terbentuk grafik TSR terhadap koefisien daya $\left(C_{P}\right)$ (trial error).

5. Jumlah iterasi yang digunakan dalam simulasi ini berdasarkan grafik monitor torsi yang sudah tidak berubah lagi terhadap jumlah iterasi (konvergen), dalam kasus ini sekitar 400500 iterasi.

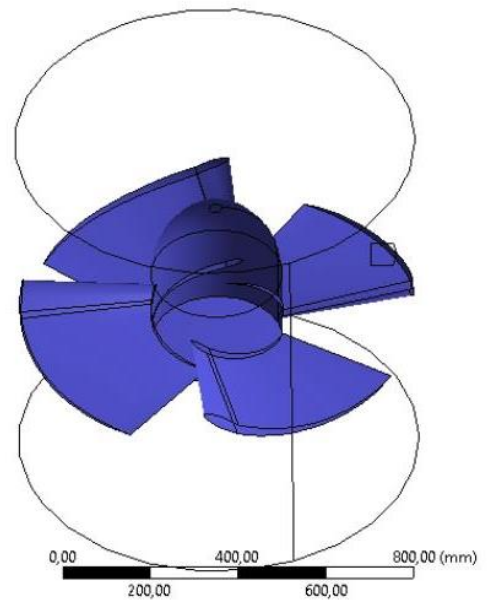

(a) Body sizing

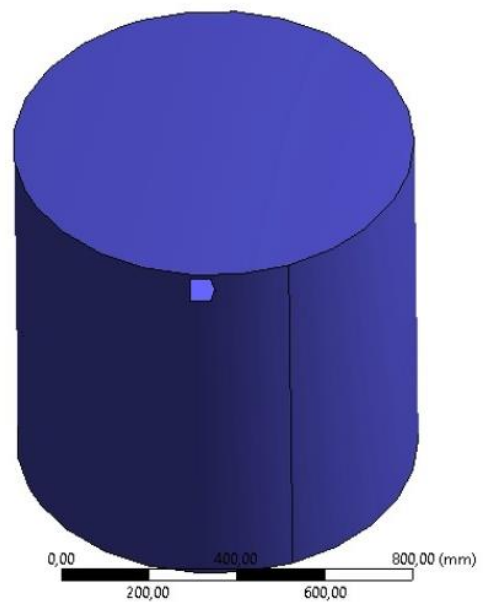

(b) Face sizing

Gambar 3 Contoh gambar dari proses a). face sizing dan b). body sizing

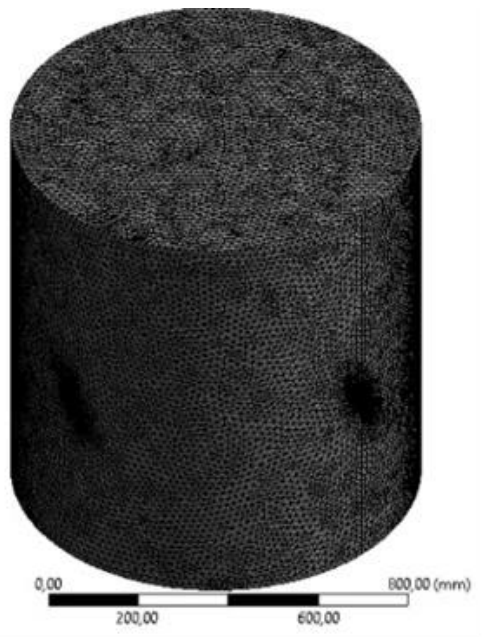

(a)

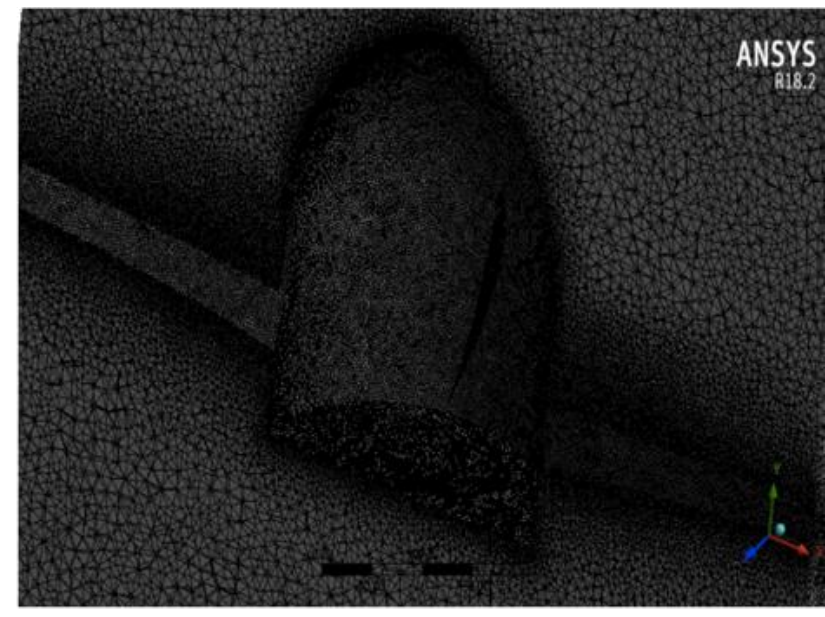

(b)

Gambar 4 Contoh gambar a dan b dari meshing pada bilah terkait

Perhitungan performa turbin $\left(C_{P}\right.$ dan $\left.T S R\right)$ 
Parameter TSR dan $C_{P}$ merupakan dua parameter non-dimensional yang dapat digunakan untuk mengukur performa turbin. Besarnya energi air yang dapat diekstrak menjadi energi mekanik yang melewati rotor dianggap sebagai efisiensi atau koefisien daya $\left(C_{P}\right)$. Koefisien daya sebuah turbin dipengaruhi oleh beberapa faktor seperti profil foil rotor, susunan foil, pengaturan foil, dan lain-lain. Koefisien daya yang melewati rotor merupakan perbandingan antara daya keluaran yang dihasilkan rotor dengan daya aliran air yang secara teoritis dirumuskan sebagai berikut:

$$
C_{p}=\frac{P}{\frac{1}{2} \rho A v^{3}}
$$

Dimana $C_{P}$ adalah koefisien daya, $P$ adalah daya (Watt), $\rho$ adalah massa jenis $\left(\mathrm{kg} / \mathrm{m}^{2}\right)$, $A$ adalah luas penampang aliran $\left(\mathrm{m}^{2}\right)$, dan $v$ adalah kecepatan arus air $(\mathrm{m} / \mathrm{s})$.

Torsi sebuah rotor turbin pada kenyataannya lebih kecil dibandingkan dengan nilai teoritis. Untuk mencari nilai torsi rotor dibutuhkan gaya thrust rotor yang dirumuskan sebagai berikut:

$$
F=\frac{1}{2} \rho A v^{2}
$$

Dengan demikian torsi rotor yang mempunyai jari jari $R$ secara teorotis dirumuskan sebagai berikut:

$$
T=\frac{1}{2} \rho A v^{2} R
$$

Koefisien torsi $\left(C_{T}\right)$ yang merupakan perbandingan antara torsi aktual dengan torsi teoritis dirumuskan sebagai berikut:

$$
C_{T}=\frac{T}{\frac{1}{2} \rho A v^{2} R}
$$

Dimana $C_{T}$ adalah koefisien daya, $T$ adalah torsi $\left(N_{m}\right)$, dan $R$ adalah jari-jari turbin $(m)$.

Untuk menentukan efisiensi interkasi antara kecepatan rotasi rotor dengan kecepatan aliran air dapat dijelaskan melalui tip speed ratio (TSR). TSR dapat dirumuskan sebagai berikut:

$$
\lambda=\frac{\omega R}{v}
$$

Dimana $\lambda$ adalah tip speed ratio, dan $\omega$ adalah kecepatan rotasi turbin $(\mathrm{rad} / \mathrm{s})$.

\section{HASIL DAN PEMBAHASAN}

Hasil analisis performa turbin, disajikan dalam beberapa data pendukung seperti distribusi tekanan, shear stress serta plot streamline berupa hasil visualisasi aliran yang terjadi ditunjukkan dalam gambar 5, 6 dan 7. Data hasil analisis komputasi terkait dengan performa turbin, yaitu torsi dan daya untuk setiap variasi masing-masing sudut pitch yang dihitung menggunakan pesamaan 1,2 dan 3 telah disusun dan disajikan pada tabel 1. Selanjutnya ketiga data tabel tersebut telah dirangkum dalam grafik koefisen daya $\left(C_{P}\right)$ terhadap TSR yang ditunjukkan dalam gambar 8. 


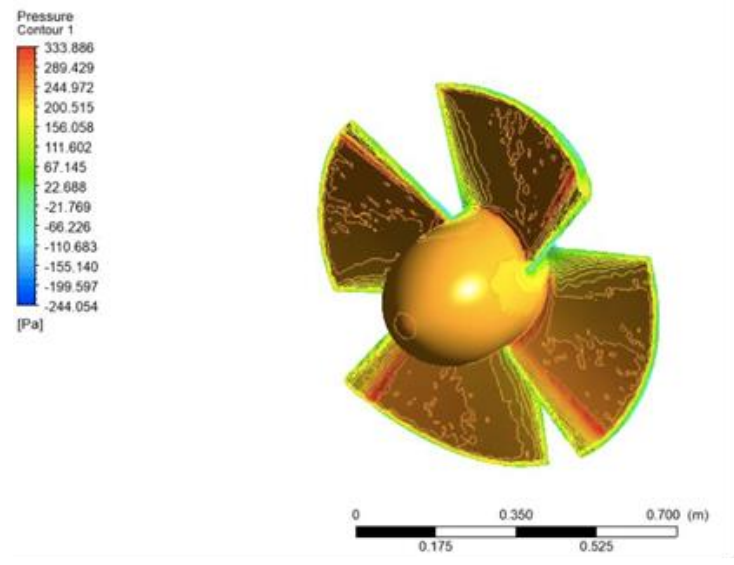

(a) Sudut picth $18^{0}$

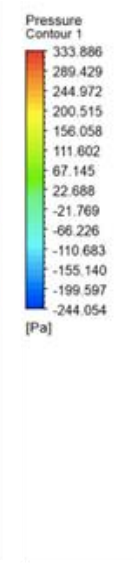

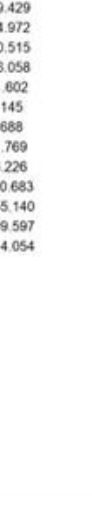

$(6)$

(b) Sudut picth $23^{0}$

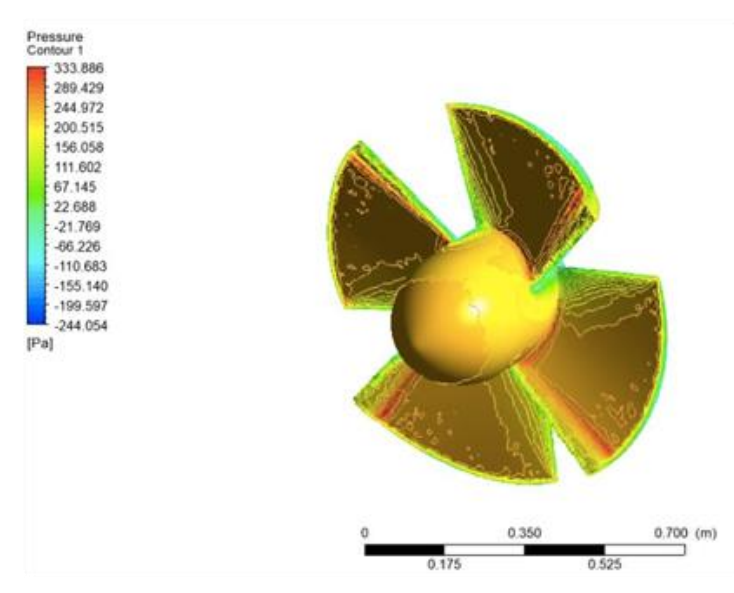

(c) Sudut picth $28^{0}$

Gambar 5 Distribusi tekanan pada permukaan rotor bahwa:

Berdasarkan hasil simulasi, distribusi tekanan yang terjadi pada bilah, dapat dijelaskan

1. Tekanan pada bagian "bawah" airfoil memiliki tekanan yang relatif lebih tinggi dibandingkan dengan bagian "atas" atau punggung airfloil. Hal ini disebabkan karena pengaruh dari geometri airfoil yang melengkung pada bagian punggung serta pengaruh dari sudut pitch yang tidak nol.

2. Distribusi tekanan yang tinggi di atas mengindikasikan dorongan bilah searah dengan arah putaran, sehingga pada kondisi ini, rotor berfungsi sebagai generator (penghasil energi). Jika torsi yang dihasilkan berlawanan dengan arah putaran, rotor berfungsi sebagai propeller (mengubah energi rotasi menjadi aliran).

3. Tekanan yang tinggi pada bagian depan nose, mengindikasikan stagnation point yaitu lokasi "tabrakan" fluida dengan dinding rotor. Tekanan yang tinggi di bagian depan tersebut menghasilkan gaya dorong ke belakang yang harus ditahan oleh thrust bearing rotor.

4. Pada bagian punggung airfoil, terdapat tekanan yang rendah, mengindikasikan daerah suction yang "menyedot" bilah berputar kearah searah dengan putaran sehingga 


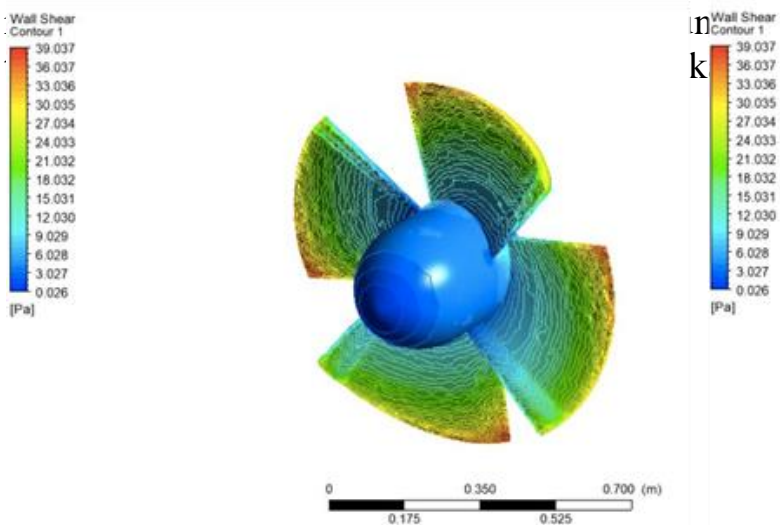

(b) Sudut picth $18^{0}$

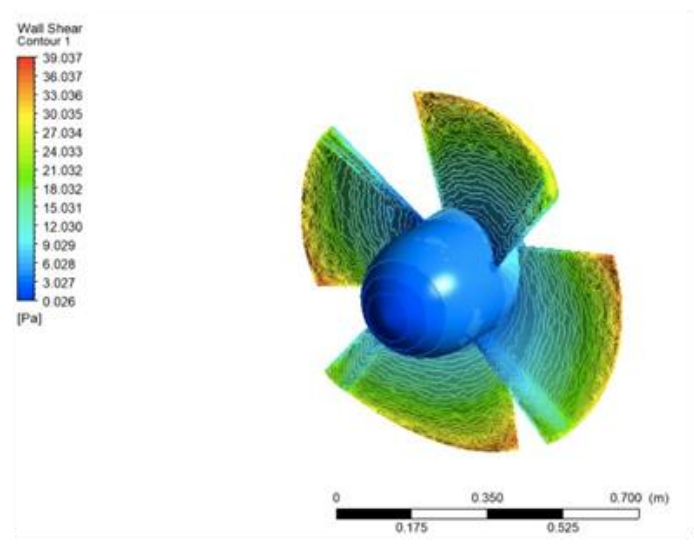

(c) Sudut picth $28^{0}$

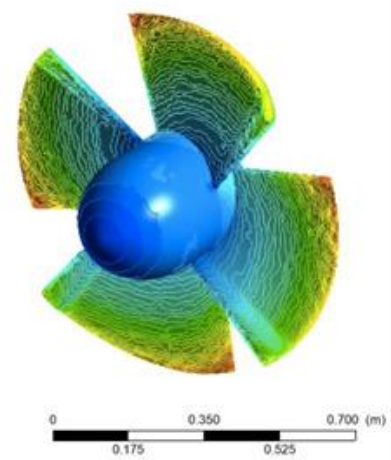

(a) Sudut picth $23^{0}$

Gambar 6 Distribusi tegangan geser pada permukaan rotor untuk masing-masing sudut

Berdasarkan hasil simulasi, distribusi tegangan geser yang terjadi pada bilah mengindikasikan besarnya beban gesekan akibat viskositas aliran fluida yang menghambat rotasi dan menurunkan efisiensi turbin. Disamping itu, tegangan geser yang besar juga beresiko abrasi yang besar juga pada lokasi tersebut. Dari gambar juga dapat dilihat bahwa tegangan geser yang besar terjadi pada punggung airfoil karena pada daerah tersebut memiliki kecepatan yang relative tinggi.

Gambar 6 distribusi tegangan geser yang terjadi pada blade memiliki kecenderungan selalu mengalami peningkatan dengan kenaikan yang tidak linier. Pada kondisi awal untuk sudut 18 derajat tegangan geser yang terjadi sebesar 1, $66 \mathrm{~Pa}$, sudut 23 derajat sebesar 1,71 Pa, dan sudut 28 derajat sebesar 1, $58 \mathrm{~Pa}$. Kondisi tersebut menunjukkan bahwa besarnya sudut tidak begitu berpengaruh terhadap tegangan geser yang terjadi. 


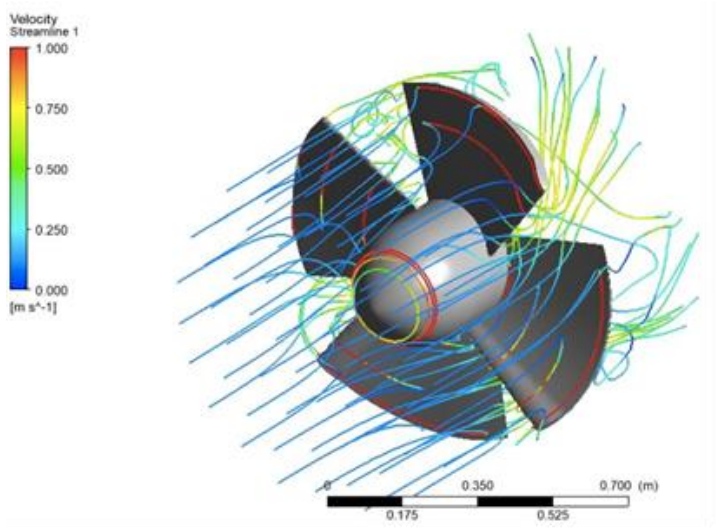

(a) Sudut picth $18^{0}$
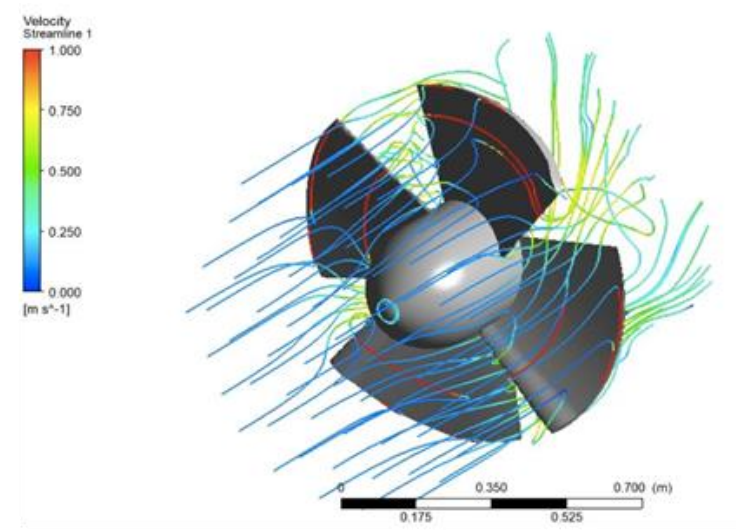

(b) Sudut picth $23^{0}$

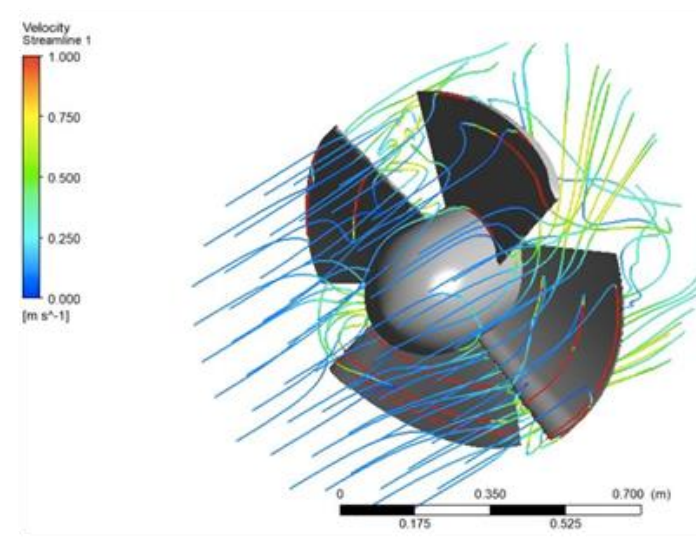

(c) Sudut picth $28^{0}$

Gambar 7 Pola streamline pada sekitar rotor

Gambar 7 memperlihatkan pola aliran yang terjadi pada bilah untuk berbagai sudut. Pola aliran yang dihasilakan masing-masing sudut terlihat jelas bahwa perubahan sudut berpengaruh terhapap pola aliran yang terjadi pada sisi belakang bilah. Semakin kecil sudut maka pola aliran terlihat semakin berbelok, sementara semakin besar sudut pola aliran semakin terlihat lurus.

Hasil perhitungan tip speed ratio (TSR) terhadap torsi (N.m) berdasarkan persamaan 1, 2, dan 3 untuk masing-masing sudut dari ketiga model bilah terkait ditunjukkan dalam table 1 .

Tabel 1 Hasil perhitungan tip speed ratio (TSR), torsi (N.m) dan daya (watt)

\begin{tabular}{|c|c|c|c|c|c|c|c|c|c|}
\hline \multirow{2}{*}{$\begin{array}{c}\boldsymbol{V} \\
\text { (mps) }\end{array}$} & \multicolumn{4}{|c|}{$\boldsymbol{T S R}$} & \multicolumn{3}{c|}{$\boldsymbol{T}(\boldsymbol{N . m})$} & \multicolumn{3}{c|}{$\boldsymbol{P}(\boldsymbol{W a t t})$} \\
\hline $\mathbf{1 8}^{\mathbf{0}}$ & $\mathbf{2 3}^{\mathbf{0}}$ & $\mathbf{2 8}^{\mathbf{0}}$ & $\mathbf{1 8}^{\mathbf{0}}$ & $\mathbf{2 3}^{\mathbf{0}}$ & $\mathbf{2 8}^{\mathbf{0}}$ & $\mathbf{1 8}^{\mathbf{0}}$ & $\mathbf{2 3}^{\mathbf{0}}$ & $\mathbf{2 8}^{\mathbf{0}}$ \\
\hline 0,5 & 10 & 138,65 & 1386,51 & 28,26 & 10 & 132,43 & 1324,32 & 26,99 & 10 \\
\hline 0,15 & 33,3 & 10,53 & 105,32 & 79,50 & 33,3 & 10,49 & 104,98 & 79,24 & 33,33 \\
\hline 0,12 & 41,7 & 6,15 & 61,54 & 90,73 & 41,67 & 5,90 & 59,05 & 87,06 & 41,66 \\
\hline 0,1 & 50 & 3,62 & 36,21 & 92,25 & 50 & 3,40 & 34,09 & 86,85 & 50 \\
\hline 0,09 & 55,6 & 2,55 & 25,47 & 89,01 & 55,55 & 2,48 & 24,87 & 86,93 & 55,55 \\
\hline
\end{tabular}




\begin{tabular}{|l|l|l|l|l|l|l|l|l|l|}
\hline 0,08 & 62,5 & 1,51 & 15,12 & 75,24 & 62,5 & 1,49 & 14,97 & 74,47 & 62,5 \\
\hline
\end{tabular}

Hubungan koefisen daya $\left(C_{P}\right)$ terhadap TSR dari tabel 1 ditunjukkan dalam gambar grafik 8 sebagai berikut:

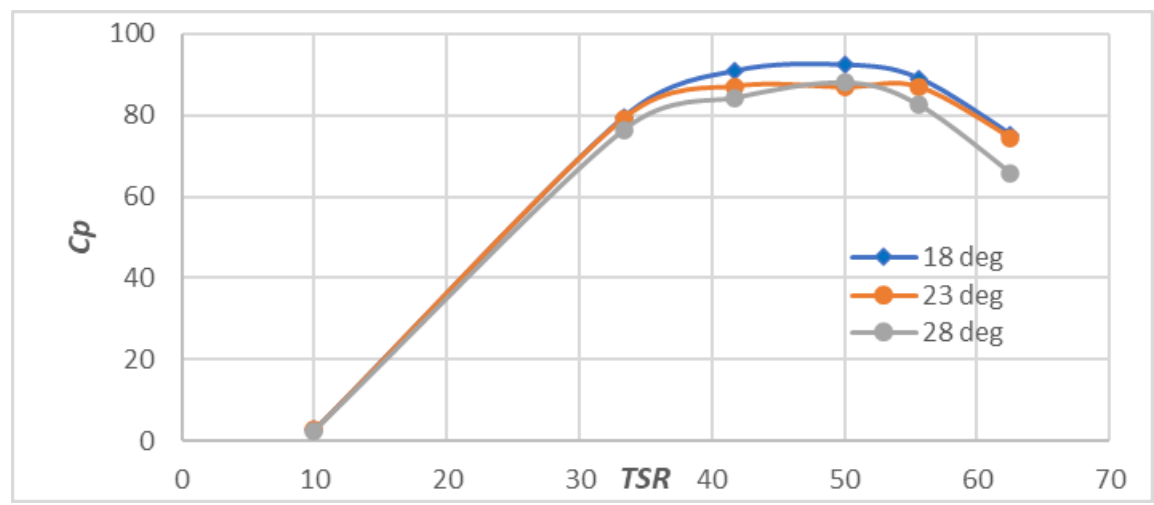

Gambar 8 Grafik Hubungan koefisen daya $\left(C_{P}\right)$ terhadap TSR

Dari gambar grafik 8 hasil perhitungan ditunjukkan bahwa bilah dengan sudut pitch $18^{0}$ dengan nilai koefisien tekan sebesar 28, 26 memiliki performa yang lebih baik dibandingkan sudut $23^{\circ}$ dan $28^{0}$ dengan nilai koefisen tekan $\left(C_{P}\right)$ maksimum masing-masing adalah 26,99 dan 25,80 . Hasil ini berbeda dengan yang diperoleh oleh peneliti sebelumnya untuk jenis turbin yang sama [19], namun demikian sudu turbin dengan sudut $23^{\circ}$ cenderung memiliki performa yang lebih tinggi dibandingkan dengan sudut $28^{\circ}$ meskipun keduanya memiliki puncak nilai koefisen tekan $\left(C_{P}\right)$ terpaut selisih 1,2 .

\section{KESIMPULAN}

Analisis CFD telah digunakan dalam studi ini sebagai alatbantu dalam menganalisis streamline yang melewati sudut inlet dan outlet pada rotor, serta di antara bilah pelari. Di sisilain, data kecepatan aliran untuk setiap parameter bilah yang terlibat juga diperoleh dari analisis khusus ini. Dari hasil akhir pada Tabel 1 ditunjukkan bahwa output daya maksimum yang dapat dihasilkan oleh turbin propeller dengan sudut $18^{0}$ adalah $1386,51 \mathrm{~W}$. Sementara nilai output minimum yang dihasilkan adalah sekitar $13,21 \mathrm{~W}$ dengan sudut $28^{\circ}$. Secara keseluruhan dapat disimpulkan bahwa sudu turbin dengan sudut pitch $18^{0}$ memiliki performa yang lebih tinggi dibandingkan dengan sudut $23^{\circ}$ dan $28^{\circ}$. Sedangkan sudut $23^{\circ}$ cenderung memiliki performa yang lebih tinggi dibandingkan dengan sudut $28^{0}$ meskipun keduanya memiliki puncak nilai koefisen daya $\left(C_{P}\right)$ yang bersesuaian.

\section{SARAN}

Percobaan lapangan perlu diimplementasikan dimana parameter dan spesifikasi yang terlibat harus sama dengan apa yang telah dilakukan dalam analisis CFD sehingga perbandingan dapat dibuat antara kedua hasil nanti.

\section{DAFTAR PUSTAKA}

[1] Date, A., \& Akbarzadeh, A. (2009). Design and cost analysis of low head simple reaction hydro turbine for remote area power supply. Renewable Energy, 34(2), 409-415.

[2] REN21. Renewbles in Cities 2019 Global Status Report. Retrieved from URL https://wedocs.unep.org/bitstream/handle/20.500.11822/28496/REN2019.pdf?sequence=1 
\&isAllowed=y\%0Ahttp://www.ren21.net/cities/wp-content/uploads/2019/05/REC-GSRLow-Res.pdf

[3] International Hydropower Association (IHA, 2013). Hydropower Report.

[4] Tasri, A., \& Susilawati, A. (2014). Selection among renewable energy alternatives based on a fuzzy analytic hierarchy process in Indonesia. Sustainable Energy Technologies and Assessments, 7, 34-44.

[5] Kusakana, K., Munda, J. L., \& Jimoh, A. A. (2008). Economic and environmental analysis of micro hydropower system for rural power supply. PECon 2008 - 2008 IEEE 2nd International Power and Energy Conference, (PECon 08), 441-444.

[6] REN21. (2017). Renewables 2017: A global status report. Renewable and Sustainable Energy Reviews (Vol. 72)

[7] Purwanto et al., (2006). Indonesia Energy Outlook and Statistics 2006. In the Energy Assessment of the University of Indonesia. https://doi.org/10.13140/RG.2.1.1798.4080

[8] Penche, Celso, dan Minas, Ingeneiro de 1998. Layman's Handbook on How to Develop A Small Hydro Plant. Second Edition, Uropean Commission: Belgia.

[9] Dietzel. F. 1993, Turbines, Pumps and Compressors, Translation Dakso Sriyono, Erlangga Publisher, Jakarta

[10] Zainuddin, H., Khamis, A., Yahaya, M. S., Basar, M. F. M., Lazi, J. M., \& Ibrahim, Z. (2009). Investigation on the performance of pico-hydro generation system using consuming water distributed to houses. Proceedings of 1 st International Conference on the Developments in Renewable Energy Technology, ICDRET 2009, 210-213.

[11] Ramos, H. M., Borga, A., Simao, M. (2009). "New design solutions for low-power energy production in water pipe systems". Water Science and Engineering, 2 (4):69-84.

[12] Ramos, H. M., Simão, M., Kenov, K. N. (2012). Low-Head Energy Conversion: A Conceptual Design and Laboratory Investigation of a Micro-Turbular Hydro Propeller. Instuto superior Técnico, Av. Rovisco Pais, 1049-001-Lisbon, Portugal.

[13] Byeon, Sun Seok, \& Kim, Y. J. (2013). Influence of bilah number on the flow characteristics in the vertical axis propeller hydro turbine. International Journal of Fluid Machinery and Systems, 6(3), 144-151.

[14] Simpson, RG, \& Williams, A. (2006). Application of computational fluid dynamics to the design of pico propeller turbines. Proceedings of the International Conference on Renewable Energy for Developing Countries

[15] Singh, P., \& Nestmann, F. (2009). Experimental optimization of a free vortex propeller runner for micro hydro application. Experimental Thermal and Fluid Science, 33(6), 9911002.

[16] Chica Arrieta, E. L., Agudelo Flórez, S., \& Sierra, N. I. (2013). Application of CFD to the Design of the Runner of a Propeller Turbine For Small Hydroelectric Power Plants. Revista Facultad de Ingeniería Universidad de Antioquia, (69), 181-192.

[17] Bozorgi, A., Javidpour, E., Riasi, A., \& Nourbakhsh, A. (2013). Numerical and experimental study of using axial pump as turbine in Pico hydropower plants. Renewable Energy, 53, 258-264.

[18] Adhikari, P., Budhathoki, U., Timilsina, S. R., Manandhar, S., \& Bajracharya, T. R. (2014). A Study on Developing Pico Propeller Turbine for Low Head Micro Hydropower Plants in Nepal. Journal of the Institute of Engineering, 9(1), 36-53.

[19] Othman, M. M et al, 2015. CFD Analysis on The Flat Runner Blades of Propeller's Turbine under Low Head and Low Flow Condition, Applied Mechanics and Materials Vol 699 (2015) pp 437-442] 